\title{
Hazardous radioactivity levels and heavy mineral concentrations in beach sediments of Lake Peipsi, northeastern Estonia
}

\author{
Johanna-Iisebel Järvelill1 ${ }^{,}$, Rein Koch ${ }^{2}$, Anto Raukas $^{3}$, Tiit Vaasma ${ }^{3}$ \\ ${ }^{1}$ School of Natural Sciences and Health, Tallinn University, Narva Road 29, 10120 Tallinn, Estonia \\ ${ }^{2}$ Institute of Physics, Tartu University, Riia 142, 51014 Tartu, Estonia \\ ${ }^{3}$ Institute of Ecology, Tallinn University, Uus-Sadama 5, 10120 Tallinn, Estonia \\ *corresponding author, e-mail: iisebel@tlu.ee
}

\begin{abstract}
The present study discusses results of heavy mineral analyses and radioactivity of beach sediments of Lake Peipsi. Such analyses are commonly done globally, but had not yet been conducted for the fourth largest lake in Europe. The average heavy mineral content in Lake Peipsi beach sediments along the northern and western coast is higher than usual for Estonian coastal and Quaternary sediments. Concomitantly, elevated radioactivity levels have been measured in several places, with the highest concentrations observed at Alajõe $(1885.5 \mathrm{~Bq} / \mathrm{kg})$, which is over five times more than the recommended limit. The aim of the present study is to find sites with higher radioactivity levels, because the northern coast of Lake Peipsi is a well-known recreational area.
\end{abstract}

Key words: elevated radioactivity, risk management, beach sediments, heavy minerals, Baltic States

\section{Introduction}

High radioactivity levels as a result of heavy mineral content in coastal sediments have been detected in many parts of the world (Mohanty et al., 2004; Vassas et al., 2006; Carvalho et al., 2011). Aerogeophysical measurements have previously suggested that high radioactivity levels are present in different parts of Estonia (Ylätalo et al., 1996) where major sources of elevated radioactivity are graptolite argillites (marinite-type alum shales, sapropelic in origin) and the Obolus phosphorite. Phosphorites are light yellowish or dark-grey, fine- or coarse-grained, slightly cemented sandy deposits that straddle the Upper Cambrian/Lower Ordovician boundary (Raudsep, 1997). In addition, there is granitoid material that was transported to Estonia by glaciers from basement rocks in Finland. Some varieties of Devonian sand- and siltstones have higher radioactivity as well. Elevated concentrations of heavy minerals have been identified in different parts of the Estonian coast (Järvelill et al., 2015). Due to complicated cross-shore and alongshore migration of sedimentary material in the coastal zone, enrichment of heavy minerals, including zircon, monazite and other radioactive minerals, has occurred, for example in the Lemme area of southwestern Estonia (Raukas et al., 2014).

Systematic mineralogical studies of Estonian bedrock and Quaternary deposits started at the beginning of the 1960s (Raukas, 1961a, b, 1965; Viiding, 1962, 1968) and specifically for the Lake Peipsi area at the start of the 1980s (Raukas, 1981; Raukas \& Rähni, 1982; Tavast, 1984), but to date there have 
not been any studies of radioactivity of Lake Peipsi beach sediments. The aim of the present study is to document sites with higher radioactivity levels and take these into account when assessing risks to human health, in view of the fact that the northern coast of Lake Peipsi is a well-known recreational area and even rather low levels of radioactivity represent a considerable threat.

\section{Description of Lake Peipsi}

Lake Peipsi, situated to the south of the Finnish Gulf on the border between Estonia and Russia, is the fourth largest lake in Europe, having a surface area of $3,555 \mathrm{~km}^{2}$. The lake consists of three parts: the northernmost, largest and deepest part is Lake Peipsi (sensu stricto) (Fig. 1), the southernmost is Lake Pihkva (Pskov) and the narrow, strait-like body of water that connects these two, is called Lake Lämmijärv (Warm Lake). The average depth of the lake is $7.1 \mathrm{~m}$, the maximum depth being $15.3 \mathrm{~m}$. It is approximately $47 \mathrm{~km}$ wide and $152 \mathrm{~km}$ long and is a remnant of proglacial lakes from the deglaciation period. Parameters of the lake can fluctuate widely with a changeable water level. The catchment basin of the lake (including the lake's surface) has an area of $47,800 \mathrm{~km}^{2}$, of which $16,323 \mathrm{~km}^{2}$ is on Estonian, $27,917 \mathrm{~km}^{2}$ on Russian and $3,650 \mathrm{~km}^{2}$ on Latvian territory, with a tiny marshy corner extending into the south of Belarus (Haberman et al., 2008).

\subsection{Geology of the study area}

With the retreat of the continental ice sheet into the Finnish Gulf, a glacial lake, Lake Peipsi, came into being. This retreat was most likely drained to the northeast, but drainage reconstruction down to its minimum level, i.e., c. $20 \mathrm{~m}$ a.s.l. (Hang, 2001), was not resolved (Rosentau et al., 2004). Glaciolacustrine sedimentation in Lake Peipsi, which took place between 13,500 and 13,100 varve years BP, correlates with the Pandivere (located to the west of Lake Peipsi) ice marginal zone of late Weichselian glaciation (Hang, 2003; Kalm et al., 2011; Amon et al., 2016).

The crystalline basement of the lake depression is found at a depth of 200-300 m, while the depression itself comprises two sedimentary units: Devonian terrigenous rocks on top of Ordovician carbonates (Fig. 2). Ordovician and Silurian carbonates crop out in the northern part of the depression (Raukas, 2003). The Ordovician-Devonian sequence shows an inclination towards the south to southeast. In the northern and central parts, this amounts to $2-2.2 \mathrm{~m}$ per $\mathrm{km}$ and in the southern part of the lake 4.5-4.9 $\mathrm{m}$ per $\mathrm{km}$; the central part is $50-60 \mathrm{~m}$ deeper than the surroundings. The southern part is characterised by a thicker succession of Devonian terrigenous rocks and in the northwestern part of the lake lies a buried valley in Devonian sedimentary bedrock (Miidel et al., 2001).

The thickness of the Quaternary cover is highly variable, ranging from a few metres in the northwest to over $50 \mathrm{~m}$ in the central part (Noormets et al., 1998). The Pleistocene sequence is rather simple, the main deposits being tills of the last glaciation and glacial meltwater deposits (Raukas, 2003). The northern part of the lake sediment cover consists of till and glaciolacustrine clay, overlain by Holocene lake deposits (Noormets et al., 1998; Hang, 2001). In the northern part of the lake, Holocene deposits, represented by a lacustrine marl up to $2 \mathrm{~m}$ thick and overlain by up to $4 \mathrm{~m}$ of gyttja, are missing from many parts of the bottom (Hang, 2001).

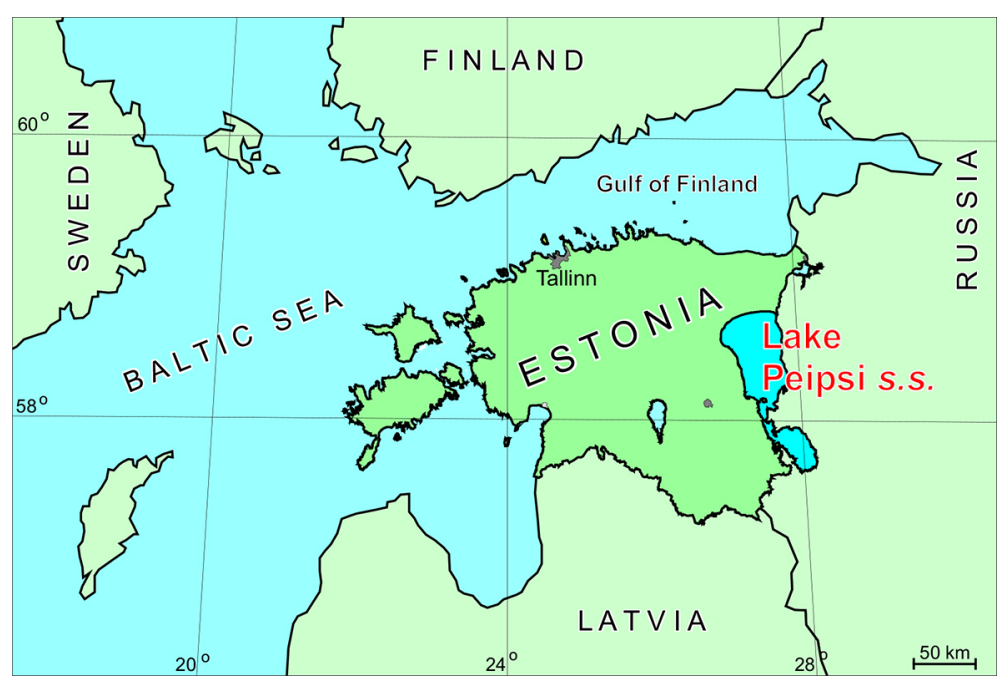

Fig. 1. Location of Lake Peipsi (sensu stricto). 


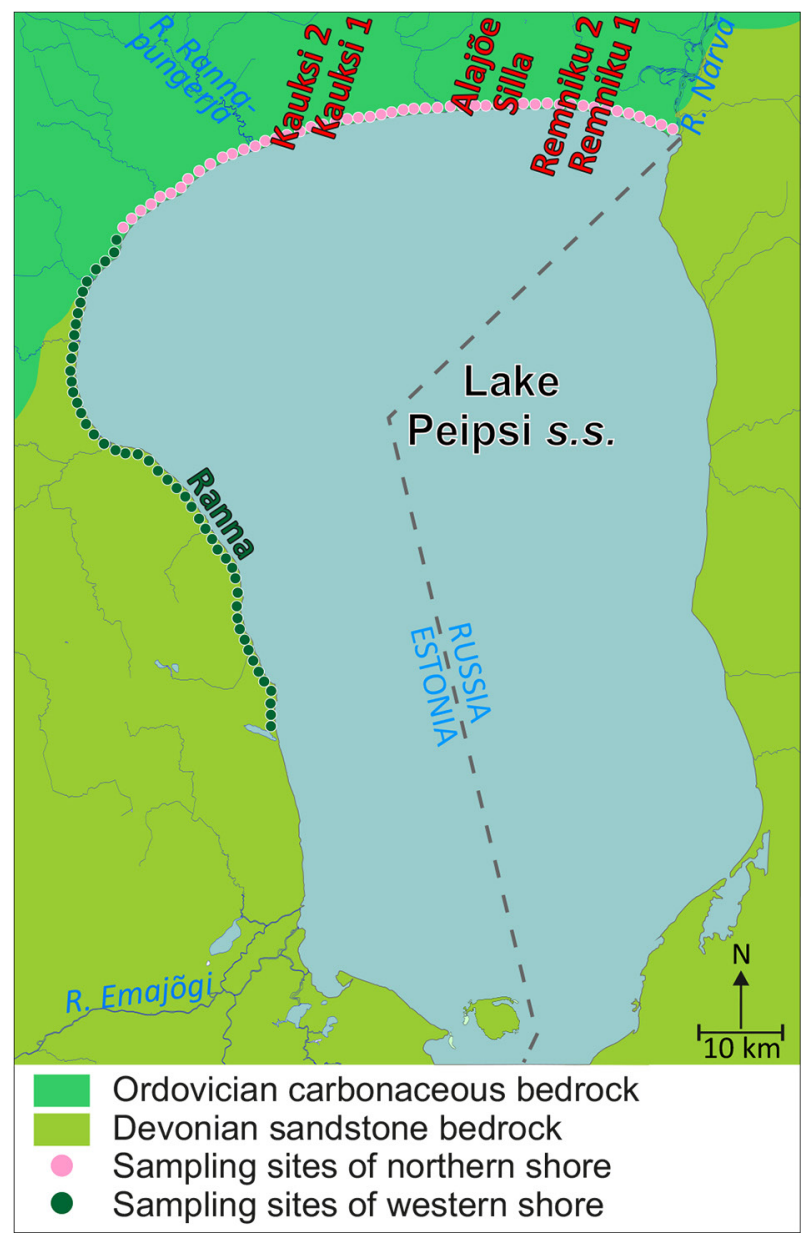

Fig. 2. Sampling locations along the northern (pink dots) and western (green dots) shores of Lake Peipsi (sensu stricto), with a simplified geological map of bedrock outcrops (Vaher, 2008; modified by Tiit Vaasma) below Quaternary strata. The seven sites for radioactivity measurements were Remniku 1 and 2, Silla, Alajōe, Kauksi 1 and 2 and Ranna.

Due to land uplift and changing coastal erosion aeolian sands accumulated. Parabolic dunes formed here with blowouts moving downwind and the low-lying arms fixed with vegetation lag behind. Dune inclination is $10-20^{\circ}$ on the windward and $20-30^{\circ}$ on the leeward slope. On the Lake Peipsi coast are spread "basket-trap dunes" (according to Orviku, 1933) that formed behind parabolic wind ditches where the vegetation cover was damaged by waves and ice action or by clearing, grazing, burning or trampling (Raukas, 2011).

The lake has an open eastern and a swampy and overgrown western shore. The prevailing southwesterly, southerly and westerly winds caused active erosional shores in the northern and eastern parts of the lake (Raukas \& Tavast, 2011). Waves commonly are $60-70 \mathrm{~cm}$ high, with the highest up to $240 \mathrm{~cm}$ (Jaani \& Raukas, 1999). Sedimentation and resedimentation of bottom and coastal deposits is influenced by lake ice, over a period of 114 days on average. Ridges of pressure ice can be up to $10 \mathrm{~m}$ in height (Raukas \& Tavast, 2011).

On the northern coast of the lake, i.e., the main object of our study, beach sediments are mostly well sorted (1.2-1.3), fine and medium-grained (0.15-0.47) sands. Medium-grained, less well-sorted sands can be found from Kauksi to the River Narva (median 0.38-0.44 mm; sorting 1.29-1.7) (Tavast \& Raukas, 1996). The mineral composition of the Lake Peipsi (sensu stricto) sediments is impacted by till and local bedrock (Raukas, 1999). The sandy beaches, for example Kauksi, on the northern coast are very popular among tourists and locals (Fig. 3).

\section{Material and methods}

The main study sites of Remniku, Silla, Alajõe, Kauksi and Ranna (Fig. 2) are important recreational areas that belong to the Estonian National Environmental Monitoring Programme. The prime task of this programme is to monitor long-term and large-scale environmental changes and to recognise situations

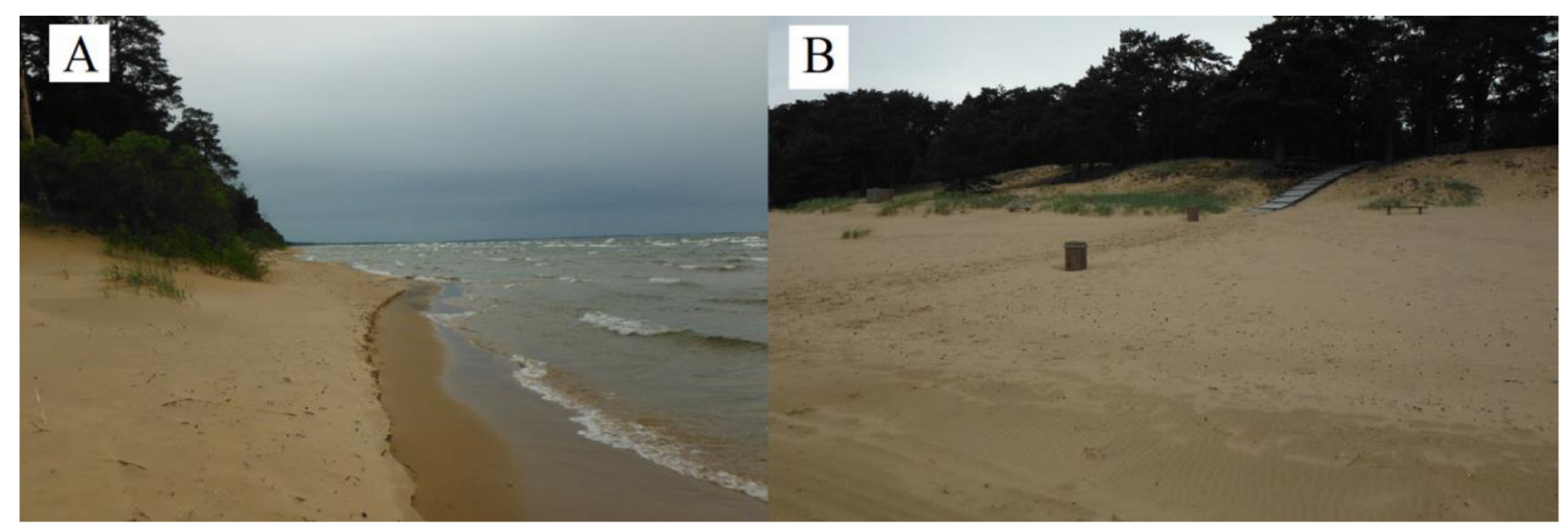

Fig. 3. Sandy beaches on the northern shore of Lake Peipsi. A - Silla; B - Kauksi. 
which require counter measures and identify problems and solutions, which call for further complementary studies. During this study of the shores of the large lakes in Estonia (i.e., Peipsi and Võrtsjärv), which have been studied every two years since 1993, changes in coastal morphology, granulometric sediment composition and assessment of impacts of human activities on the coast have been measured (Raukas \& Tavast, 2011; Vaasma et al., 2016).

In our study, 99 samples were analysed; 50 from the northern and 49 from the western coast. Samples were collected from beach sediments, backshore and beach face (Fig. 4), with a distance of 1 $\mathrm{km}$ between samples (from Kauksi and Remniku were collected two samples after every $200 \mathrm{~m}$ ). Grain size analyses needed for the analyses of mineral content and radioactivity were conducted with an Analysette 3 Vibratory Sieve Shaker PRO using a sieve set with nine fractions $(>2,000,>1,000,>500$, $>250,>125,>100,>63,>36$ and $0-36 \mu \mathrm{m})$ or with a Retsch Vibratory Sieve Shaker type AS200 Basic for radioactivity analysis, using a sieve set with seven fractions (>500, >250, >150, >106, >75, >38 and 0-38 $\mu \mathrm{m})$. Grain size is not discussed in the results and discussion chapters to preclude deviation from the topic. The light and heavy (over $2.89 \mathrm{~g} / \mathrm{cm}^{3}$ ) mineral suites were separated. The immersion method was applied, making use of liquids with refractive indexes of 1.54 and 1.64 (Larsen \& Berman, 1934; Stoiber \& Morse, 1994). About 300 mineral grains from the light subfraction and 500 grains of the heavy subfraction were counted in each mineral suite on glass slides using a polarising microscope.

The sieved sample fractions from Remniku, Silla, Alajõe, Kauksi and Ranna, as well as integral (bulk) sand samples, were studied using a gamma spectrometer. These samples were first dried at $105^{\circ} \mathrm{C}$

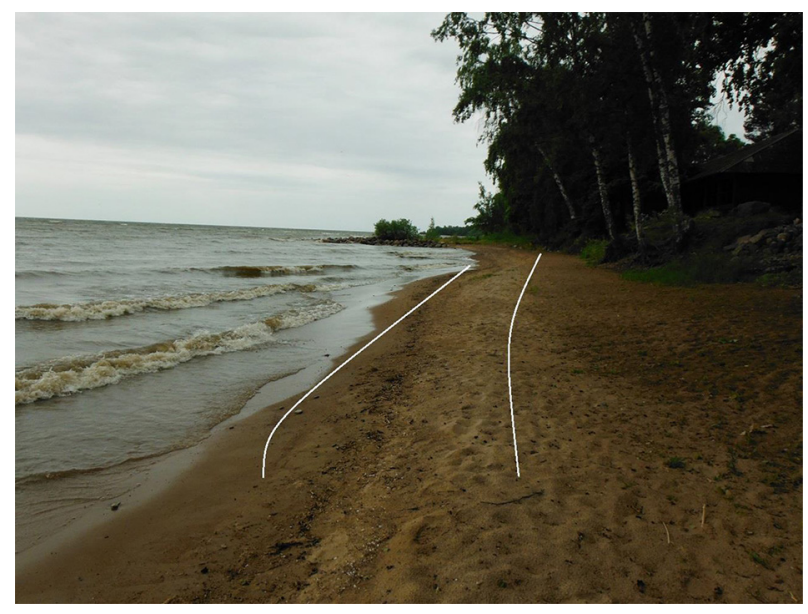

Fig. 4. The site of Ranna, with the zone of sample collection marked: backshore and beach face. and then weighed. From each sample, an aliquot was taken and placed in an airtight $55 \mathrm{~cm}^{3}$ metal beaker and sealed. When dried, the remaining sample material was sieved into fractions $(>2,000,>1,000$, $>500,>250,>150$ or $>125,>106$ or $>100,>75$ or $>63$, $>38$ and $0-38 \mu \mathrm{m})$. The sealed beakers were stored for at least 28 days to form a secular equilibrium between Rn-222 and its progeny. Two types of metal beakers were used: $55 \mathrm{~cm}^{3}$ beakers made from steel if there was sufficient material to fill them and 100 $\mathrm{cm}^{3}$ aluminium beakers with an epoxy resin if there was only a small amount of sample material. For the gamma analyses, this small amount of material was mixed with 5 gr of epoxy resin. Afterwards, this 100 $\mathrm{cm}^{3}$ aluminium beaker was sealed. After 28 days, these hermetically sealed beakers were analysed by gamma-ray spectroscopy. The measurements were performed by a coaxial, high-purity germanium detector (HPGe) (GEM-35200, EG\&G Ortec). The resultant spectra were analysed using the International Atomic Energy Agency (IAEA) analysis programs, Gamma- and Neutron- Activation Analysis Software (GANAAS) and Cambio. The spectrometer was calibrated using IAEA standard uranium ore (RGU1), thorium ore (RGTh-1) and potassium sulphate (RGK-1). The activity concentration of U-238 in the sample was calculated using a gamma line of Th-234 (63.3 keV) and gamma lines of the Ra-226 daughter nuclides $\mathrm{Pb}-214$ and $\mathrm{Bi}-214$, under the assumption that U-238 is in secular equilibrium with the daughter nuclide of Ra-226. This is consistent with how it was considered in previous studies in the Lemme area coastal sands in southwestern Estonia (Koch, 2006; Raukas et al., 2014). The activity concentration of Th-232 in the sample was determined using the gamma lines of Th-232 daughter nuclides as Ac-228, Bi-212, Pb-212 and Tl-208. The activity concentration of K-40 was determined using the $1460.7 \mathrm{keV}$ emission gamma line, while that of U-235 was not calculated separately. The influence of the Ac-228 gamma peak of $1459.19 \mathrm{keV}$, with a gamma yield of $1.06 \%$ to the K-40 gamma peak of $1460.7 \mathrm{keV}$, with gamma yield of $10.67 \%$, have not been taken into account (De Meijer et al., 2001). It should be noted that $1 \mathrm{~Bq}$ of activity concentration for Th-232 would contribute less than $0.1 \mathrm{~Bq}$ to the K-40 activity concentration.

The radium equivalent index $\mathrm{Ra}_{\mathrm{eq}}$ is given by the following formula (Beretka \& Mathew, 1985):

$$
\mathrm{Ra}_{\mathrm{eq}}=\mathrm{A}_{\mathrm{Ra} 226}+1.43 \mathrm{~A}_{\mathrm{Th} 232}+0.077 \mathrm{~A}_{\mathrm{K} 40}
$$

where $\mathrm{A}_{\mathrm{Ra} 226}, \mathrm{~A}_{\mathrm{Th} 232}$ and $\mathrm{A}_{\mathrm{K} 40}$ are the activity concentrations in $\mathrm{Bq} / \mathrm{kg}$ of the corresponding radionuclides in the sample. The recommended limit for $\mathrm{Ra}_{\text {eq }}$ values is less than $370 \mathrm{~Bq} / \mathrm{kg}$ (UNSCEAR, 1982). 


\section{Results}

\subsection{Mineral composition}

Mineral composition differentiates samples from the northern and western shores (i.e., areas marked in different colours; Fig. 2) with a greater heavy mineral content in northern shore samples (Table 1). On the northern shore, a lower feldspar content and higher content of heavy minerals, in particular those for ore minerals and zircon, are observed. On the western shore, iron hydroxide content is higher. The zircon content in the north is $4.2 \%$ and in the west decreases to the medium level of $2.6 \%$. The garnet content is $27.9 \%$ in the north, and nearly identical in the west, $27.2 \%$. The content of ore minerals is higher on the northern shore $(28.1 \%)$ than on the western shore (22.1\%).

The average heavy mineral content in 92 samples is $1.1 \%$, but when results for seven anomalously enriched samples are included, this value increases to $3.6 \%$ (Table 2). The highest heavy mineral content compared to other samples from Peipsi coast was found in samples from Remniku 1, Alajõe and Silla (Table 3).

In all samples, in the fraction $125-250 \mu \mathrm{m}$, quartz $(83.7 \%)$ predominates over feldspars (16\%). Among the seven anomalous samples, the K-feldspar content is $15.3 \%$. In the heavy subfraction ore minerals $(25.7 \%)$ and garnets $(27.6 \%)$ are the prevailing minerals, while the median zircon content was $3.6 \%$ (Table 2).

In the finer fractions (100-125 $\mu \mathrm{m})$, the heavy mineral content is higher in comparison to the coarser fraction $(125-250 \mu \mathrm{m})$. Samples most suitable to analysis were collected from the sites of Remniku 1 (99.6\% of heavy minerals) (Fig. 5) and Ranna (82.2\% of heavy minerals).
Table 1. Comparison of the mineral content on western and northern shores of Lake Peipsi (sensu stricto) (content lower than $0.1 \%$ marked with " + ").

\begin{tabular}{|c|c|c|}
\hline & $\begin{array}{c}\text { Western beaches } \\
(\%)\end{array}$ & $\begin{array}{c}\text { Northern beaches } \\
(\%)\end{array}$ \\
\hline \multicolumn{3}{|c|}{ Light minerals } \\
\hline Quartz & 79.2 & 86.6 \\
\hline Feldspars & 20.2 & 13.2 \\
\hline Micas & 0.2 & 0 \\
\hline Carbonates & 0.4 & + \\
\hline \multicolumn{3}{|c|}{ Heavy minerals } \\
\hline Iron hydroxides & 3.5 & 0.9 \\
\hline Pyrite & + & 0.5 \\
\hline Leucoxene & 0.9 & 1 \\
\hline Anatase & + & 0 \\
\hline Biotite & 3.2 & 0.2 \\
\hline Chlorides & 0 & + \\
\hline Ore minerals & 22.1 & 28.1 \\
\hline Garnets & 27.2 & 27.9 \\
\hline Zircon & 2.6 & 4.2 \\
\hline Tourmaline & 1.3 & 1.3 \\
\hline Apatite & 1.9 & 0.7 \\
\hline Rutile & 0.1 & + \\
\hline Titanite & 0.1 & 0.2 \\
\hline Epidote & 1.8 & 2.7 \\
\hline Andalusite & + & 0.4 \\
\hline Amphiboles & 27.4 & 26.3 \\
\hline Pyroxenes & 2.6 & 4.1 \\
\hline Dolomite & 0.6 & 0.1 \\
\hline Kyanite & 0.1 & 0.1 \\
\hline Olivine & 0.1 & 0.1 \\
\hline Zoisite & + & + \\
\hline Staurolite & 0.5 & 0.4 \\
\hline Sillimanite & 0.2 & 0.8 \\
\hline Biogenic apatite & 3.8 & + \\
\hline Topaz & 0 & + \\
\hline Fluorite & + & 0 \\
\hline Sphalerite & + & 0 \\
\hline $\begin{array}{l}\text { Heavy subfrac- } \\
\text { tion }\end{array}$ & 1.7 & 4.9 \\
\hline
\end{tabular}

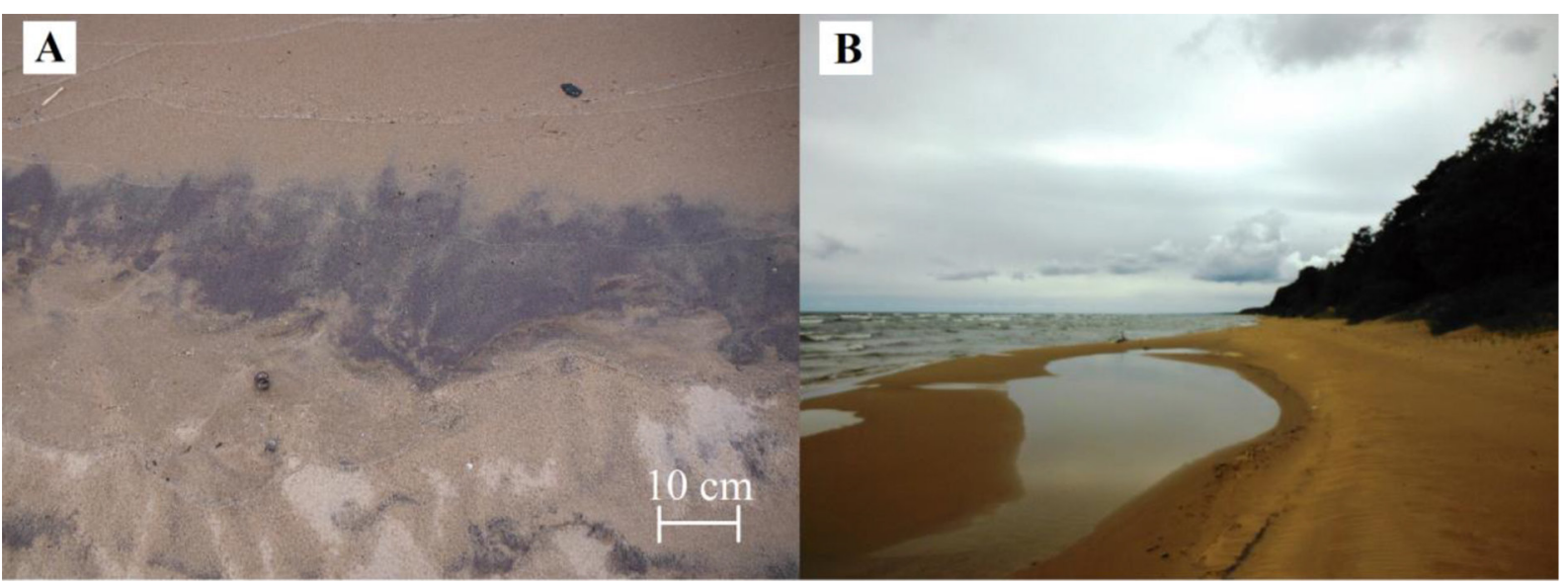

Fig. 5. Higher heavy mineral concentrations at the Remniku 1 site (A, B). Heavy minerals are visual (dark zone distinguished, A). 
Table 2. Percentages of minerals in the samples studied; fraction $125-250 \mu \mathrm{m}$ (content lower than $0.1 \%$ marked with " + ").

\begin{tabular}{|c|c|c|c|c|c|c|}
\hline & $\begin{array}{c}\text { Mean } \\
(\%)\end{array}$ & $\begin{array}{l}\text { Min } \\
(\%)\end{array}$ & $\begin{array}{c}\operatorname{Max} \\
(\%)\end{array}$ & Median & Variance $(n-1)$ & Standard deviation (n-1) \\
\hline \multicolumn{7}{|c|}{ Light minerals } \\
\hline Quartz & 83.7 & 68.1 & 96 & 0.843 & 0.004 & 0.065 \\
\hline Feldspars & 16 & 4 & 31 & 0.156 & 0.004 & 0.063 \\
\hline Micas & 0.1 & 0 & 2.7 & 0 & 0 & 0.004 \\
\hline Carbonates & 0.2 & 0 & 2.6 & 0 & 0 & 0.005 \\
\hline \multicolumn{7}{|c|}{ Heavy minerals } \\
\hline Iron hydroxides & 2 & 0 & 21.2 & 0.011 & 0.001 & 0.03 \\
\hline Pyrite & 0.3 & 0 & 30.6 & 0 & 0.001 & 0.031 \\
\hline Leucoxene & 1 & 0 & 39.2 & 0 & 0.002 & 0.04 \\
\hline Anatase & 0.01 & 0 & 0.4 & 0 & 0 & 0 \\
\hline Biotite & 1.4 & 0 & 56.6 & 0 & 0.005 & 0.068 \\
\hline Chlorides & + & 0 & 0.5 & 0 & 0 & 0 \\
\hline Ore minerals & 25.7 & 0.4 & 61.2 & 0.248 & 0.017 & 0.132 \\
\hline Garnets & 27.6 & 6.6 & 47.8 & 0.294 & 0.01 & 0.102 \\
\hline Zircon & 3.6 & 0 & 13.7 & 0.032 & 0.001 & 0.026 \\
\hline Tourmaline & 1.3 & 0 & 6.1 & 0.01 & 0 & 0.011 \\
\hline Apatite & 1.1 & 0 & 4.6 & 0.01 & 0 & 0.011 \\
\hline Rutile & 0.1 & 0 & 0.7 & 0 & 0 & 0.001 \\
\hline Titanite & 0.1 & 0 & 1 & 0 & 0 & 0.002 \\
\hline Epidote & 2.4 & 0 & 11.6 & 0.02 & 0 & 0.021 \\
\hline Andalusite & 0.3 & 0 & 7.3 & 0 & 0 & 0.009 \\
\hline Amphiboles & 26.7 & 0 & 75.7 & 0.238 & 0.028 & 0.168 \\
\hline Pyroxenes & 3.5 & 0 & 35.2 & 0.028 & 0.002 & 0.04 \\
\hline Dolomite & 0.3 & 0 & 2.4 & 0 & 0 & 0.005 \\
\hline Kyanite & 0.06 & 0 & 2.9 & 0 & 0 & 0.002 \\
\hline Olivine & 0.1 & 0 & 3.8 & 0 & 0 & 0.005 \\
\hline Zoisite & 0.02 & 0 & 0.6 & 0 & 0 & 0.001 \\
\hline Staurolite & 0.4 & 0 & 3 & 0.004 & 0 & 0.005 \\
\hline Sillimanite & 0.5 & 0 & 4.4 & 0.002 & 0 & 0.008 \\
\hline Biogenic apatite (broken fossil shells) & 1.5 & 0 & 20.8 & 0 & 0.002 & 0.039 \\
\hline Topaz & + & 0 & 0.2 & 0 & 0 & 0 \\
\hline Fluorite & 0.01 & 0 & 0.4 & 0 & 0 & 0.001 \\
\hline Sphalerite & + & 0 & 0.2 & 0 & 0 & 0 \\
\hline Heavy subfraction & 3.6 & 0.04 & 71.6 & & & \\
\hline Light subfraction & 96.4 & 28.4 & 99.96 & & & \\
\hline
\end{tabular}

The seven anomalous samples (Table 3) were also analysed for finer fractions, 100-125 $\mu \mathrm{m}$ and 63-100 $\mu \mathrm{m}$. In the 100-125 $\mu \mathrm{m}$ fraction, the zircon content was found to be present at an average level

Table 3. Percentages of heavy and light minerals in anomalously enriched samples (fraction 125-250 $\mu \mathrm{m}$ ).

\begin{tabular}{lcc}
\multicolumn{1}{c}{ Site } & Heavy minerals (\%) & Light minerals (\%) \\
\hline Remniku 1 & 71.6 & 28.4 \\
\hline Remniku 2 & 17.5 & 82.5 \\
Silla & 57.4 & 42.6 \\
Alajõe & 61.6 & 38.4 \\
Kauksi 1 & 9.4 & 90.6 \\
Kauksi 2 & 2.0 & 98.0 \\
Ranna & 23.9 & 76.1
\end{tabular}

of $7.6 \%$ (six samples), with a maximum found in the Kauksi 1 sample with a zircon content of $15.8 \%$. In the $63-100 \mu \mathrm{m}$ fraction the zircon content increases to an average of $9.6 \%$, with the highest content found in the Remniku 1 sample, i.e., $21.1 \%$. The content of ore minerals is higher in the fraction 100-125 $\mu \mathrm{m}$ at $50.3 \%$ (the highest ore mineral content was found in an Alajõe sample at $62.4 \%$ ). In the fraction $63-100 \mu \mathrm{m}$ the ore mineral content is lower at $37.6 \%$, with the highest content found in the Silla sample at $65.5 \%$. It should be noted that these samples are from levels enriched in heavy minerals and they do not characterise the entire sample site.

The assemblage of heavy minerals shows high contents of semi-resistant minerals $(27.6 \%$ garnet, 


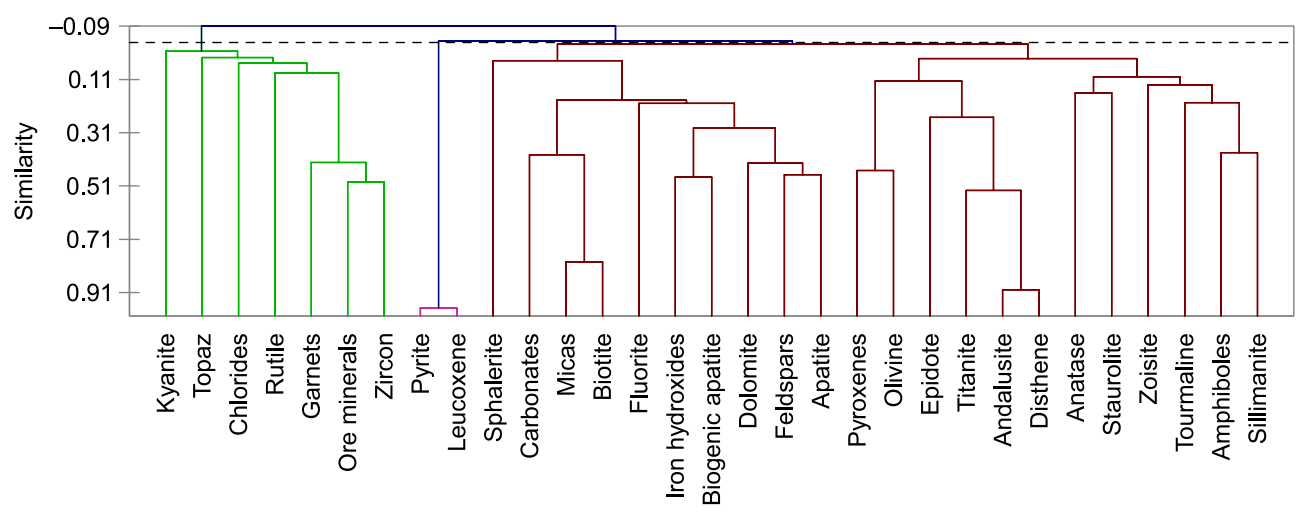

Fig. 6. Agglomerative hierarchical clustering analysis of minerals in beach deposits of Lake Peipsi (sensu stricto). Final clusters emerge above the dotted line.

$2.4 \%$ epidote), although the non-resistant mineral content is also high $(26.7 \%$ amphiboles) and the resistant minerals content quite low (3.6\% zircon, $0.4 \%$ staurolite, $0.06 \%$ kyanite, $1.3 \%$ tourmaline, $0.1 \%$ rutile, $0.3 \%$ andalusite, $1.1 \%$ apatite, $0.1 \%$ titanite).

There are three groups of minerals according to an agglomerative hierarchical clustering (AHC) analysis (Fig. 6) used for assessment of the mineral content of samples. In the first group, the heaviest minerals are observed, such as zircon, garnets, rutile and ore minerals. Pyrite and leucoxene form the second group and the third group, which is the largest, comprises various types of minerals.

\subsection{Radioactivity analysis}

Fractions for which activity concentration of U-238, Th-232 and K-40, as well the radium equivalent $\left(\mathrm{Ra}_{\mathrm{eq}}\right)$ and ratio of thorium to uranium from seven sampling sites were calculated, are listed in Table 4.

The activity concentration of Th-232 in bulk samples varies from $6.5 \mathrm{~Bq} / \mathrm{kg}$ (Kauksi 2) to 1,007.3 Bq/ $\mathrm{kg}$ (Alajõe), which is a difference of about 155 times. The activity concentration of U-238 in bulk samples varies from $7.96 \mathrm{~Bq} / \mathrm{kg}$ (Kauksi 2) to $427.55 \mathrm{~Bq} / \mathrm{kg}$ (Alajõe), which is a difference of more than 53 times. The activity concentration of K-40 in bulk samples

Table 4. Grain size distribution of beach sand samples of Lake Peipsi and activity concentrations of radionuclides (Th232, U-238 and K-40) in different fractions.

\begin{tabular}{|c|c|c|c|c|c|c|}
\hline Sites, grain size $(\mu \mathrm{m})$ & Content in the sample (\%) & Th-(Bq/kg) & U-(Bq/kg) & $\mathrm{K}-(\mathrm{Bq} / \mathrm{kg})$ & Ra-eq. & $\mathrm{Th} / \mathrm{U}$ \\
\hline Remniku 1 & bulk sample & $140.27(4.00)$ & $219.83(2.32)$ & $130.26(0.01)$ & 357.208 & 0.932 \\
\hline$>500$ & 0.707 & & & & & \\
\hline$>250$ & 54.324 & $20.41(0.97)$ & $32.44(0.78)$ & $183.26(0.01)$ & 75.748 & 0.629 \\
\hline$>150$ & 36.776 & $278.48(6.60)$ & $474.00(3.80)$ & $69.64(0.01)$ & 877.591 & 0.588 \\
\hline$>106$ & 1.622 & 1372(155) & 1639(17) & $114.66(0.01)$ & 3608.3 & 0.837 \\
\hline$>75$ & 0.023 & & & & & \\
\hline$>38$ & 0.003 & & & & & \\
\hline Remniku 2 & bulk sample & $37.12(1.13)$ & $28.03(0.97)$ & $259.97(0.01)$ & 92.294 & 1.288 \\
\hline$>500$ & 0.007 & & & & & \\
\hline$>250$ & 80.462 & 6.10(0.49) & $6.01(0.47)$ & $262.53(0.01)$ & 4.94 & 1.015 \\
\hline$>125$ & 19.354 & $174.76(3.96)$ & $125.30(2.12)$ & $228.74(0.01)$ & 392.82 & 1.395 \\
\hline$>100$ & 0.128 & 2337.4(69.9) & $848.31(51.31)$ & $373.19(0.01)$ & 4219.51 & 2.755 \\
\hline$>63$ & 0.042 & $894.77(65.95)$ & $384.80(100)$ & $344.19(0.01)$ & 1690.83 & 2.325 \\
\hline$>36$ & & 0.004 & & & & \\
\hline Silla & bulk sample & $44.483(1.05)$ & $80.79(0.83)$ & $138.30(0.01)$ & 155.038 & 0.551 \\
\hline$>500$ & 2.066 & $6.54(4.6)$ & $8.01(1.00)$ & $254.18(0.01)$ & 36.94 & 0.817 \\
\hline$>250$ & 81.127 & $11.84(0.60)$ & $14.07(0.65)$ & $143.37(0.01)$ & 42.04 & 0.842 \\
\hline$>125$ & 16.78 & $189.51(5.76)$ & $388.69(5.45)$ & $70.09(0.01)$ & 665.085 & 0.488 \\
\hline$>100$ & 0.018 & & & & & \\
\hline$>63$ & 0.004 & & & & & \\
\hline Alajõe & bulk sample & $1007.3(21.5)$ & $427.55(4.18)$ & $227.00(0.01)$ & 1885.51 & 2.356 \\
\hline$>500$ & 14.218 & $9.90(0.57)$ & $8.26(0.68)$ & $354.88(0.01)$ & 49.746 & 1.199 \\
\hline$>250$ & 27.758 & $138.90(4.39)$ & $66.90(1.96)$ & $303.02(0.01)$ & 288.862 & 2.076 \\
\hline
\end{tabular}




\begin{tabular}{lcccccc}
\hline Sites, grain size $(\mu \mathrm{m})$ & Content in the sample $(\%)$ & Th- $(\mathrm{Bq} / \mathrm{kg})$ & $\mathrm{U}-(\mathrm{Bq} / \mathrm{kg})$ & $\mathrm{K}-(\mathrm{Bq} / \mathrm{kg})$ & Ra-eq. & Th/U \\
\hline$>150$ & 45.404 & $1427.2(30.8)$ & $630.90(6.16)$ & $158.51(0.01)$ & 2684.053 & 2.262 \\
$>106$ & 5.396 & $5089.4(107.4)$ & $362.4(14.4)$ & $391.24(0.01)$ & 8670.33 & 3.736 \\
$>75$ & 0.096 & $10724(272)$ & $004.6(107)$ & $578.03(0.02)$ & 18384.41 & 3.569 \\
$>38$ & 0.006 & $1185(381)$ & $673.34(193.34)$ & $0.00(0.01)$ & 2367.245 & 1.759 \\
\hline Kauksi 1 & bulk sample & $44.73(1.20)$ & $35.55(0.95)$ & $229.54(0.01)$ & 117.196 & 1.258 \\
$>500$ & 0.077 & $0.000(0.0)$ & $25.10(6.06)$ & $211.78(0.01)$ & 41.4 & 0 \\
$>250$ & 75.837 & $20.66(0.80)$ & $19.30(0.93)$ & $244.95(0.01)$ & 67.706 & 1.07 \\
$>125$ & 23.985 & $107.13(2.51)$ & $83.77(1.54)$ & $173.11(0.01)$ & 250.287 & 1.279 \\
$>100$ & 0.094 & $4985(147)$ & $2329(101)$ & $263.72(0.01)$ & 9478.504 & 2.141 \\
$>63$ & 0.005 & & & & & \\
\hline Kauksi 2 & bulk sample & $6.50(0.55)$ & $7.96(0.66)$ & $411.50(0.01)$ & 48.937 & 0.816 \\
$>500$ & 0.948 & $11.80(2.83)$ & $11.72(2.23)$ & $394.59(0.01)$ & 58.977 & 1.006 \\
$>250$ & 92.559 & $6.04(0.50)$ & $6.11(0.51)$ & $385.53(0.01)$ & 44.433 & 0.989 \\
$>125$ & 6.465 & $12.59(0.61)$ & $15.97(0.80)$ & $279.44(0.01)$ & 55.486 & 0.789 \\
$>100$ & 0.014 & & & & & \\
$>63$ & 0.006 & & & & & \\
\hline Ranna & bulk sample & $47.81(1.66)$ & $40.44(1.09)$ & $670.40(0.01)$ & 160.439 & 1.182 \\
$>500$ & 27.689 & $19.52(1.00)$ & $17.33(0.80)$ & $1170.37(0.01)$ & 135.364 & 1.126 \\
$>250$ & 41.212 & $22.49(1.18)$ & $16.68(0.84)$ & $614.24(0.01)$ & 96.137 & 1.348 \\
$>150$ & 20.514 & $337.61(8.10)$ & $237.94(2.73)$ & $122.07(0.01)$ & 730.123 & 1.419 \\
$>106$ & 1.433 & $519.20(19.90)$ & $409.86(3.97)$ & $168.57(0.01)$ & 1165.291 & 1.267 \\
$>75$ & 0.246 & $822.22(26.50)$ & $820.7(29.0)$ & $436.97(0.02)$ & 2030.074 & 1.002 \\
$>38$ & 0.063 & $609.55(29.52)$ & $458.3(38.4)$ & $983.45(0.03)$ & 1405.691 & 1.33 \\
$0-38$ & 0.03 & $95.61(18.34)$ & $78.41(21.6)$ & $1033.71(0.04)$ & 294.736 & 1.219 \\
\hline
\end{tabular}

varies from $130.26 \mathrm{~Bq} / \mathrm{kg}$ (Remniku 1) to 670.40 $\mathrm{Bq} / \mathrm{kg}$ (Ranna), which is a difference of more than five times. The activity concentration of Th-232 and $\mathrm{U}-238$ is highly dependent on particle size. The highest activity concentration for Th-232 $(10,724 \mathrm{~Bq} / \mathrm{kg})$ was found in the 75-106 $\mu \mathrm{m}$ fraction from the Alajõe sampling site and the highest activity concentration for U-238 $(3,004.6 \mathrm{~Bq} / \mathrm{kg})$ was measured in the same sample. The maximum K-40 activity concentration $(1170.37 \mathrm{~Bq} / \mathrm{kg})$ was found in the $>500 \mu \mathrm{m}$ fraction from the Ranna sampling site. A high concentration of potassium $(>1,000 \mathrm{~Bq} / \mathrm{kg}$ ) was observed for samples from Ranna $(1,170.37 \mathrm{~Bq} / \mathrm{kg})$ in the $>500 \mu \mathrm{m}$ fraction and $(1,033.71 \mathrm{~Bq} / \mathrm{kg})$ in the $0-38 \mu \mathrm{m}$ fraction, whereby activity concentrations for Th and $\mathrm{U}$ in these samples were rather low. The thorium/uranium ratio for bulk samples is less than 2.0, except for the sample from Alajõe (2.356), whereby for samples from Remniku 1, Silla and Kauksi 2, the value is below 1.0. The radium equivalent index for bulk samples was calculated from the $\mathrm{Ra}_{226} \mathrm{Th}_{232}$ and $\mathrm{K}_{40}$ concentrations, and varied from $48.94 \mathrm{~Bq} / \mathrm{kg}$ (Kauksi 2) to $1,885.5 \mathrm{~Bq} / \mathrm{kg}$ (Alajõe).

The mean measured values of thorium, uranium and potassium contents from bulk samples ranges between $6.50 \mathrm{~Bq} / \mathrm{kg}$ (Kauksi 2) and 1,007.3 Bq/ kg (Alajõe) for Th; from 7.96 Bq/ kg (Kauksi 2) to 427.55 $\mathrm{Bq} / \mathrm{kg}$ (Alajõe) for $\mathrm{U}$; and from $130.26 \mathrm{~Bq} / \mathrm{kg}$ (Remniku 1) to $670.40 \mathrm{~Bq} / \mathrm{kg}$ (Ranna) for K. The world- wide average concentrations of these radionuclides are: $35 \mathrm{~Bq} / \mathrm{kg}$ for $\mathrm{U}$ (Ra-226), $30 \mathrm{~Bq} / \mathrm{kg}$ for Th-232 and $400 \mathrm{~Bq} / \mathrm{kg}$ for K-40 (UNSCEAR, 2000). The average nuclide concentrations in Estonian soils are as follows: $510 \mathrm{~Bq} / \mathrm{kg}$ for $\mathrm{K}-40,35 \mathrm{~Bq} / \mathrm{kg}$ for Ra-226 and $27 \mathrm{~Bq} / \mathrm{kg}$ for Th-232. The maximum concentration of Th-232 in our bulk samples exceeds the Estonian mean value by about 34 times, while the maximum concentration of U-238 exceeds the mean

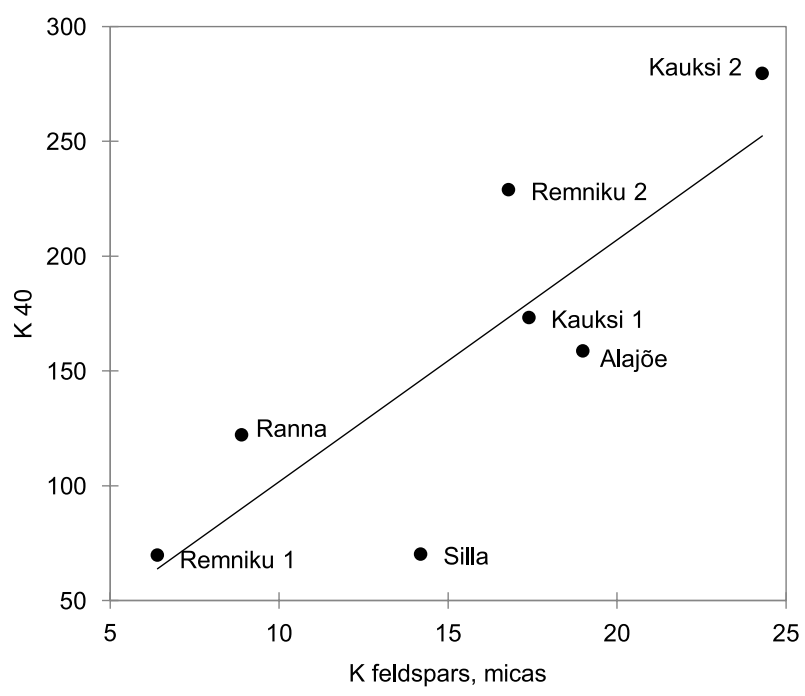

Fig. 7. Scatter plot for K-40 vs K-feldspars and content of micas. 


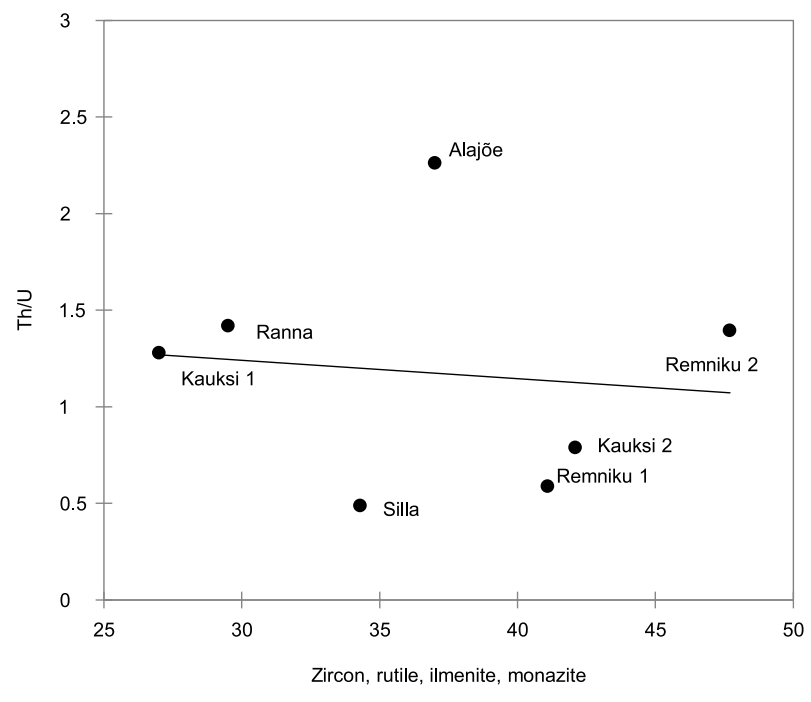

Fig. 8. Scatter plot for Th/U vs content of zircon, rutile, ilmenite and monazite.

value by about 12 times, and about 1.3 times for the concentration of K-40. Considering that $1 \mathrm{ppm}$ of $\mathrm{eU}$ and $\mathrm{eTh}$ corresponds to $12.3 \mathrm{~Bq} / \mathrm{kg}$ and $4.0 \mathrm{~Bq} /$ $\mathrm{kg}$, the calculated maximum contents of Th- 232 and U-238 in samples (from the Alajõe fraction $>75 \mu \mathrm{m}$ ) is 2,638 ppm for eTh and $243 \mathrm{ppm}$ for eU.

The thorium/uranium ratio for bulk samples is less than 2.0, except for the sample from the Alajõe sampling point, whereby for samples from Remniku 1, Silla and Kauksi 2, the Th/U ratio remains below 1.0. The radium equivalent index for bulk samples, calculated from the $\mathrm{Ra}_{226} \mathrm{Th}_{232}$ and $\mathrm{K}_{40}$ concentrations, varied from $48.94 \mathrm{~Bq} / \mathrm{kg}$ (Kauksi 2) up to $1,885.5 \mathrm{~Bq} / \mathrm{kg}$ (Alajõe), which exceeds the recommended limit of $370 \mathrm{~Bq} / \mathrm{kg}$ by over five times (UNSCEAR, 1982).

\section{Discussion}

\subsection{Mineral composition}

Beach sediments have bedrock and glacial sources and are modified by coastal hydraulic processes connected with wave action, storms, wind and water level changes. Therefore, higher heavy mineral concentrations on the northern shore $(4.9 \%)$ than the western shore $(1.7 \%)$ are observed.

In India, Kurian et al. (2001) identified that the cause of heavy mineral enrichment was monsoon activity (swells) and winnowing which had an influence on the swell period. They noted that mineral content of denser heavy minerals such as opaques (ilmenite and magnetite), monazite and zircon con- tent decreased, while lighter minerals such as sillimanite, hypersthene (pyroxene) and hornblende increased in an offshore direction. Other authors, e.g., Pupienis et al. (2013), documented that the heavy mineral content on the surface of the beaches was influenced by wave and wind action. These tendencies are also observed in our samples. The highest contents of opaques and zircon were found near the shoreline at backshore and beach face. Heavy mineral concentrations are connected to the sites affected by heavy winds and more pronounced water level changes. Lighter minerals are eroded by wind and waves. Heavy mineral accumulation is characterised by an increase of ore minerals, garnets, amphiboles and zircon. Also, in Lake Peipsi (sensu stricto) already half a metre of water level rise can lead to serious damage and erosion.

Beach sediment composition is characterised by mineral concentrations with similar densities. Minerals with higher densities mostly appear together, e.g., garnets, zircon and ore minerals (Fig. 6). These denser minerals are more concentrated on the northern shore of Lake Peipsi (sensu stricto).

Kalińska-Nartiša et al. (2015) showed in their work near Lake Peipsi that the aeolian sediments contained $13-28 \%$ of feldspars in the fraction of $0.5-0.8 \mathrm{~mm}$ and $12-34 \%$ of feldspars in the fraction of $0.8-1.0 \mathrm{~mm}$. Our results are $4-31 \%$ of feldspars in the $0.125-0.25 \mathrm{~mm}$ fraction, thus showing more equally distributed results and decreased contents.

Near the Rannapungerja River (Fig. 2), some changes in the mineral content due to the influence of the river can be observed. The heavy mineral content here is only $0.6 \%$. The fluvial processes influence the heavy mineral content by decreasing it. It is assumed that the heavy minerals are flushed away by the river flow.

Garnet, which is highly resistant to mechanical abrasion and medium resistant to chemical weathering (Morawski, 1968), is abundant in the samples. This content is increased in the eroded and redeposited beaches (Racinowski, 1974, 1992; Marcinkowski \& Mycielska-Dowgiałło, 2013). The high content of amphiboles indicates that mechanical abrasion has not been high (Goździk, 1980; Manikowska, 1985; Krzyszkowski, 1995; Mycielska-Dowgiałło, 1995; Marcinkowski \& Mycielska-Dowgiałło, 2013), but they are slightly more resistant to chemical weathering than are pyroxenes. This means that amphibole content should decrease in deposits affected by long-lived aeolian processes, but in our samples the content is high. Where Racinowski $(1974,1992)$ and Marcinkowski \& Mycielska-Dowgiałło (2013) noted that the beach and nearshore sands had the lowest content of amphiboles and the highest content of 
garnets in the $0.12-0.25 \mathrm{~mm}$ fraction, this does not apply to our samples. The beach should be enriched by minerals that are resistant to mechanical abrasion, but in our samples from Lake Peipsi amphibole content is high.

\subsection{Radioactivity analysis}

Thorium, uranium and potassium contents are influenced by the mineral compositions of sediments and rocks. There is a strong dependence of radionuclide concentration on grain size in the sand samples, which has been previously observed by other authors (De Meijer, 1998; De Meijer et al., 2001; Seddeek et al., 2005; Koch, 2006; Madruga et al., 2014). Smaller grain size generally is associated with higher activity concentrations. The content of Th and U in samples from Lake Peipsi is closely related to the grain size of the sample, this being significantly higher than in coarser fractions. For all samples with an elevated content of Th and $U$, this is observed only for fractions with a grain size less than $250 \mu \mathrm{m}$. However, this does not apply in the case of K-40 activity concentrations.

The average Th/ $\mathrm{U}$ ratio for bulk samples is similar to that found in coastal sands of western Estonia (Koch, 2006) and varies from 0.55 to 2.36, which is less than the well-known literature value of 2-2.5 (Mahdavi, 1963; Abdel-Halim \& Saleh, 2016).

The potassium content is mostly strongly correlated (Pearson correlation coefficient 0.819) with the presence of K-feldspars and micas (Fig. 7). Potassium still occurs in rock-forming minerals after disintegration of source rocks. The sample from the Ranna sampling point indicates an elevated K-40 content of $1,170.4 \mathrm{~Bq} / \mathrm{kg}$ in the $>500 \mu \mathrm{m}$ fraction, $983.5 \mathrm{~Bq} / \mathrm{kg}$ in the $>38 \mu \mathrm{m}$ fraction and $1,033.7$ $\mathrm{Bq} / \mathrm{kg}$ in the $0-38 \mu \mathrm{m}$ fraction. Uranium and thorium atoms are mostly bound to accessory and dark-coloured minerals (heavy minerals with red, purple or black colour; compare Carvalho et al., 2011). Our samples show a negative correlation between the U/Th concentration and the content of zircon, rutile, ilmenite, monazite (Fig. 8) (Pearson correlation coefficient -0.113 ).

\section{Conclusions}

At several sites on the beaches of Lake Peipsi (sensu stricto), elevated heavy mineral concentrations have been found. Among these heavy mineral accumulations we found also higher concentrations of Th and $U$, highest in Alajõe and higher than the rec- ommended (UNSCEAR, 1982) and usual concentrations in Estonia. The radium equivalent index $\mathrm{Ra}$ for the sample from Alajõe exceeds the recommended limit more than five times (UNSCEAR, 1982). These concentrations should be taken into account, as they may present a risk to human health. This hazard, however, is decreased by the fact that these concentrations are found only in enriched samples, which are located within narrow-accumulated stripes of sand.

The high content of heavy minerals is due to large fluctuations in the water of the lake and rather heavy winds. In addition, fluvial processes have some influence by inversely decreasing the heavy mineral content. The sites studied that belong to the National Monitoring Programme have rather high concentrations of heavy minerals. At the Ranna site, the content of heavy minerals in the 100-125 $\mu \mathrm{m}$ attains up to $82.2 \%$ at some levels.

\section{Acknowledgements}

We are grateful to Kalev Järvelill for assistance during fieldwork and the Tallinn University Centre of Excellence "Natural Sciences and Sustainable Development" for funding the research.

\section{References}

Abdel-Halim, A.A. \& Saleh, I.H., 2016. Radiological characterization of beach sediments along the Alexandria-Rosetta coasts of Egypt. Journal of Taibah University for Science 10, 212-220.

Amon, L., Saarse, L., Vassiljev, J., Heinsalu, A. \& Veski, S., 2016. Timing of the deglaciation and the late-glacial vegetation development on the Pandivere Upland, North Estonia. Bulletin of the Geological Society of Finland $88,69-83$.

Beretka, J. \& Mathew, P.J., 1985. Natural radioactivity of Australian building materials, industrial wastes and by-products. Health Physics 48, 87-95.

Carvalho, C., Anjos, R.M., Veiga, R. \& Macario, K., 2011. Application of radiometric analysis in the study of provenance and transport processes of Brazilian coastal sediments. Journal of Environmental Radioactivity 102, 185-192.

De Meijer, R.J., 1998. Heavy minerals: from "Edelstein" to Einstein. Journal of Geochemical Exploration 62, 81-103.

De Meijer, R.J., James, I.R., Jennings, P.J. \& Koeyers, J.E., 2001. Cluster analysis of radionuclide concentrations in beach sand. Applied Radiation and Isotopes 54, 535542.

Goździk, J., 1980. Zastosowanie mikroskopii i graniformametrii do badań osadów kopalni węgla brunatnego "Bełchatów" [The role of micromorphologic anal- 
yses in investigations of the deposits in the Bełchatów open-cast mine]. Studia Regionalne 4, 101-114.

Haberman, J., Timm, T. \& Raukas, A., 2008. Foreword. [In:] J. Haberman, T. Timm \& A. Raukas (Eds): Peipsi. Eesti Loodusfoto, Tartu, 7-12.

Hang, T., 2001. Proglacial sedimentary environment, varve chronology and Late Weichselian development of the Lake Peipsi, eastern Estonia. Doctoral thesis, Stockholm University, $44 \mathrm{pp}$.

Hang, T., 2003. A local clay-varve chronology and proglacial sedimentary environment in glacial Lake Peipsi, eastern Estonia. Boreas 32, 2, 416-426.

Jaani, A. \& Raukas, A., 1999. Location and topography. Lake Peipsi and its catchment area. [In:] A. Miidel \& A. Raukas (Eds): Lake Peipsi. Geology. Sulemees Publishers, Tallinn, 9-14.

Järvelill, J.-I., Kleesment, A. \& Raukas, A., 2015. Accumulation of heavy minerals in the eastern coast of the Gulf of Riga, south-western Estonia. Bulletin of the Geological Society of Finland 87, 67-78.

Kalińska-Nartiša, E., Nartišs, M., Thiel, C., Buylaert, J.B. \& Murray, A.S., 2015. Late-glacial to Holocene aeolian deposition in northeastern Europe - The timing of sedimentation at the Iisaku site (NE Estonia). Quaternary International 357, 70-81.

Kalm, V., Raukas, A., Rattas, M. \& Lasberg, K., 2011. Pleistocene glaciations in Estonia. [In:] J. Ehlers, P.L. Gibbard \& P.D. Hughes (Eds): Quaternary glaciations - extent and chronology. A closer look. Elsevier, Amsterdam, 95-104.

Koch, R., 2006. The radioactivity of black sand of Estonian shore of the Baltic Sea. [In:] T.K. Ikäheimonen (Ed.): STUK-A217: Ympäriston radioaktiivisuus Suomessa - 20 vuotta Tshernobylista; Helsinki [STUK-A217: Environmental radioactivity in Finland - 20 years since the Chernobyl accident; Helsinki]. Dark Oy, Vantaa, 165-168 (in Finnish).

Krzyszkowski, D., 1995. An outline of the Pleistocene stratigraphy of the Kleszczów Graben, Bełchatów outcrop, central Poland. Quaternary Sciences Review 14, 61-83.

Kurian, N.P., Prakash, T.N., Jose, F. \& Black, K.P., 2001. Hydrodynamic processes and heavy mineral deposits of the Southwest Coast, India. Journal of Coastal Research Special Issue 34, 154-163.

Larsen, E.S. \& Berman, H., 1934. The microscopic determination of the nonopaque minerals. Second edition, U. S. Geological Survey Bulletin 848. United States Department of Interior, Washington, D.C, 226 pp.

Madruga, M.J., Silva, L., Gomes, A.R., Libânio, A. \& Reis, M., 2014. The influence of particle size on radionuclide activity concentrations in Tejo River sediments. Journal of Environmental Radioactivity 132, 65-72.

Mahdavi, A., 1963. The thorium, uranium, and potassium contents of Atlantic and Gulf coast beach sands. Doctoral thesis, Rice University, $67 \mathrm{pp}$.

Manikowska, B., 1985. O glebach kopalnych, stratygrafii i litologii wydm Polski środkowej [On the palaeosols, stratigraphy and lithology of the dunes in central Poland]. Acta Geographica Lodziensia 52, 1-137.
Marcinkowski, B. \& Mycielska-Dowgiałło, E., 2013. Heavy-mineral analysis in Polish investigations of Quaternary deposits: a review. Geologos 19, 5-23.

Miidel, A., Noormets, R., Hang, T., Flodén, T. \& Bjerkéus, M., 2001. Bedrock geology and topography of the Lake Peipsi depression, eastern Estonia. GFF 123, 15-22.

Mohanty, A.K., Sengupta, D., Das, S.K., Saha, S.K. \& Van, K.V., 2004. Natural radioactivity and radiation exposure in the high background area at Chhatrapur beach placer deposit of Orissa, India. Journal of Environmental Radioactivity 75, 15-33.

Morawski, J., 1968. Spostrzeżenia nad odpornością i typem granatów w piaskach różnych środowisk sedymentacyjnych [Types and weathering resistance of garnets from the sands of different sedimentary environments]. Annales Universitatis Marie-Curie Skłodowska 20, 27-54.

Mycielska-Dowgiałło, E., 1995. Wybrane cechy teksturalne osadów [Some textural features of deposits and their significance for interpretations]. [In:] E. Mycielska-Dowgiałło \& J. Rutkowski (Eds): Badania osadów czwartorzędowych. Wybrane metody i interpretacja wyników [Investigations of Quaternary sediments. Some methods and interpretation of the results]. University Press, Warszawa, 29-105.

Noormets, R., Flodén, T., Bjerkéus, M., Hang, T., \& Miidel, A., 1998. Seismic stratigraphy of quaternary deposits in Lake Peipsi, Eastern Estonia. GFF 120, 1, 47-52.

Orviku, K.. 1933. Tuiskliiv [Drifting sand]. Loodus, Tartu, 64 pp (in Estonian).

Pupienis, D., Buynevich I.V., Jarmalavičius, D., Žilinskas, G., \& Fedorovič, J., 2013. Regional distribution of heavy-mineral concentrations along the Curonian Spit coast of Lithuania. Proceedings 12th International Coastal Symposium (Plymouth, England), Journal of Coastal Research SI 65, 1844-1849.

Racinowski, R., 1974. Dynamika środowiska sedymentacyjnego strefy brzegowej Pomorza Zachodniego w świetle badań minerałów ciężkich i uziarnienia osadów [Dynamics of the seashore sedimentary environment: a record in heavy-mineral and grain-size data]. Prace Naukowe Politechniki Szczecińskiej, Instytut Inżynierii Wodnej 4, 1-156.

Racinowski, R., 1992. Charakterystyka standardowych cech litologicznych rumowiska strefy brzegowej morza Pobrzeża Szczecińskiego [Standard lithological features of seashore sediments of the Szczecin Baltic coast]. [In:] Badania strefy brzegowej Battyku [Research of the Baltic coast]. Prace Naukowe Politechniki Szczecińskiej, Szczecin, 459, 2, 5-93.

Raudsep, R., 1997. Phosphorite. [In:] A. Raukas \& A. Teedumäe (Eds): Geology and mineral resources of Estonia. Estonian Academy Publishers, Tallinn, 331-336.

Raukas, A., 1961a. Application of the mineralogical method to the investigation of tills in Estonia. [In:] K. Orviku (Ed.): Eesti NSV Teaduste Akadeemia Geoloogia Instituudi uurimused VII. [Proceedings of the Institute of Geology of the Estonian Academy of Sciences VII]. Academy of Sciences of the Estonian SSR, Tallinn, 65-66 (in Estonian with English and Russian summaries). 
Raukas, A., 1961b. The mineralogy of the Estonian tills. Proceedings of the Estonian Academy of Sciences. Series of Physical-Mathematical and Technical Sciences 10, 3, 244-258 (in Russian with English summary).

Raukas, A., 1965. Fresh experience gained in the application of mineralogical analysis to Estonian Quaternary deposits. [In:] A. Rõõmusoks (Ed.): Proceedings of geology. University of Tartu, 68-79 (in Russian with Estonian and English summaries).

Raukas, A., 1981. On the lithological composition of bottom deposits in the Pihkva-Peipsi Lake. [In:] A. Raukas (Ed.): Bottom deposits of Lake Peipsi-Pihkva. AN ÉSSR, Tallinn, 23-41 (in Russian with English and Estonian summaries).

Raukas, A., 1999. Quaternary cover. Stratigraphy and main features of lithology. Pleistocene deposits. [In:] A. Miidel \& A. Raukas (Eds): Lake Peipsi. Geology. Sulemees Publishers, Tallinn, 32-42.

Raukas, A., 2003. Formation and development of the Lake Peipsi. [In:] Eesti suurjärved [Big lakes of Estonia]. Estonian Academy of Sciences, Tallinn, 5-12 (in Estonian).

Raukas, A., 2011. Evolution of aeolian landscapes in north-eastern Estonia under environmental changes. Geographia Polonica 84, 117-126.

Raukas, A., Koch, R., Jüriado, K. \& Järvelill, J.-I., 2014. Anomalous radioactivity level and high concentrations of heavy minerals in Lemme area, South-West Estonia. Baltica 27, 2, 93-104.

Raukas, A. \& Rähni, E., 1982. Bottom sediments and geological history of Pskovsko-Chudskoe Lake. [In:] Late Cenozoic history of the USSR lakes. Nauka, Novosibirsk, 117-123 (in Russian).

Raukas, A. \& Tavast, E., 2011. Monitoring and management of the coasts of Lake Peipsi, Eastern Europe. Journal of Coastal Conservation 15, 4, 547-553.

Rosentau, A., Hang, T. \& Miidel, A., 2004. Simulation of the shorelines of glacial Lake Peipsi in eastern Estonia during the Late Weichselian. Geological Quarterly 48, 4, 299-307.

Seddeek, M.K., Badran, H.M., Sharshar, T. \& Elnimr, T., 2005. Characteristics, spatial distribution and vertical profile of gamma-ray emitting radionuclides in the coastal environment of North Sinai. Journal of Environmental Radioactivity 84, 21-50.

Stoiber, R.E. \& Morse, S.A., 1994. Crystal identification with the polarizing microscope. Chapman and Hall, London, $358 \mathrm{pp}$.

Tavast, E., 1984. On the geology of the northern coast of Lake Peipsi. Proceedings of the Academy of Sciences of the Estonian SSR, Geology 33, 27-32 (in Russian with English and Estonian summaries).

Tavast, E. \& Raukas, A., 1996. Geological development of the northern coast of Lake Peipsi. Journal of Coastal Research 12, 4, 1024-1033.

UNSCEAR, 1982. Ionizing radiation: sources and biological effects. United Nations Scientific Committee on the Effects of Atomic Radiation. Report to the General Assembly, with Annexes.

UNSCEAR, 2000. Sources and effects of ionizing radiation. United Nations Scientific Committee on the Effects of Atomic Radiation. Report to the General Assembly, with Scientific Annexes.

Vaasma, T., Terasmaa, J. \& Vandel, E., 2016. Estonian National Environmental Monitoring Programme: Monitoring of the shores of Lake Peipsi 2016 (report in Institute of Ecology at Tallinn University and webpage of National Environmental Monitoring programme).

Vaher, R., 2008. Peipsi nõo aluspõhi [Bedrock of Lake Peipsi basin]. [In:] J. Haberman, T. Timm \& A. Raukas (Eds): Peipsi. Eesti Loodusfoto, Tartu, 13-16 (in Estonian).

Vassas, C., Pourcelot, L., Vella, C., Carpéna, J., Pupin, J.-P., Bouisset, P. \& Guillot, L., 2006. Mechanisms of enrichment of natural radioactivity along the beaches of the Camargue, France. Journal of Environmental Radioactivity 91, 146-159.

Viiding, H., 1962. On mineralogic composition of Estonian Middle-Devonian sandstones. [In:] D. Kaljo \& R. Männil (Eds): ENSV Teaduste Akadeemia Geoloogia Instituudi uurimused 10 [Studies of the Institute of Geology of the Estonian Academy of Sciences 10]. Institute of Geology of the Academy of Sciences of the Estonian SSR, Tallinn, 261-272 (in Russian with summaries in Estonian, English and German).

Viiding, H., 1968. Lithology, mineralogy and genesis of terrigenous Devonian deposits in the North Baltic. [In:] V.S. Yablokov (Ed.): Genesis and classification of sedimentary rocks. International geological congress, XXIII session, reports of Soviet geologists, problem 8. Nauka, Moscow, 75-81 (in Russian).

Ylätalo, S., Karvonen, J., Honkamaa, T., Ilander, T. \& Toivonen, H., 1996. Dose-rate mapping and search of radioactive sources in Estonia. STUK-A134. Edita OY, Helsinki, 51 pp.

Manuscript submitted: 9 August 2017 Revision accepted: 17 February 2018 